\title{
A Phenomenological Analysis on Evaluation of Sports Management Department Curriculum by Sports Sciences Faculty Members
}

\author{
Ebru Araç Ilgar ${ }^{1, *}$ \& Bekir Barış Cihan ${ }^{1}$ \\ ${ }^{1}$ University of Yozgat Bozok, School of Physical Education and Sports, Yozgat, Turkey \\ *Correspondence: School of Physical Education and Sports, University of Yozgat Bozok, Yozgat, Turkey. Tel: \\ 90-544-462-7151. E-mail: ebruarac@hotmail.com
}

Received: June 20, 2018

doi: $10.5430 /$ jct.v7n2p139
Accepted: October 11, $2018 \quad$ Online Published: November 18, 2018

URL: https://doi.org/10.5430/jct.v7n2p139

\begin{abstract}
The aim of this study is evaluating the curriculum of sports management department, which is offered by sports sciences faculties and schools of physical education and sports, by faculty members. With this study, which is constructed on qualitative research methods and a phenomenological pattern, instead of statistical generalizations, analytical generalizations were performed, a hypothesis was formed and hypothetical theorems were proposed. "Convenience Sampling", which is a form of purposive sampling, was chosen as the method of sampling. Semi-structured interview forms were used during data collection. Interview data were put down on paper and organized, and themes were created by determining meaningful data. In accordance with the themes, categories were formed and findings were extracted. In the light of obtained data, faculty members point out that the existing curriculum helps students' professional development with theoretical classes such as sports law, sports economy, administration, economics and sports management. In contrast, they also mentioned negative aspects of the curriculum such as scarcity of applied classes, inadequate sports facilities, lack of sectoral collaboration and inefficiency of sports management applications. It is envisioned that findings of this study will improve the preparation and organization processes of sports management curriculums of sports sciences faculties and schools of physical education and sports.
\end{abstract}

Keywords: sports sciences, sports management, phenomenology, curriculum

\section{Introduction}

The expected outcome from education is the development of mankind and a planned execution for this development. Planning is the stage, where expectations and abilities of both the individual and the society are thoroughly examined. In this manner, it is easier for goals and behaviors to manifest themselves through people's lives.

New formations in social and economic areas and advancements in science and technology expand duties and service areas of all organizations, and at the same time make it more difficult and complicated to carry out those responsibilities. These organizations are also required to meet the expectations of the society. Because of these reasons, management qualities have changed in this day and age (Doğu, 2011). Considering the fact that sports is a social phenomenon, sports management was conceived since the elements of sports organizations are individuals and society.

Sports managers are people, who play a role in different levels of deployment and management of sports services and activities (Cankalp, 2005). They are also responsible for sports organization's personnel, facilities and tools, and organization's finances. They can be defined as people, who utilize all resources and organize human relations of an organization, deploy, manage and lead the organization in a certain direction and influence it in accordance with organization's goals.

According to Chappelet (2009), when sports management is examined, it is determined that a globalized concept of sports and sports industry have become to run their own dynamics. Considering sports management as a discipline played a big role in the development of sports.

Sports management is a job that requires crucial skills in alignment with general purpose of sports. In order for a sports manager, who is working in sports service industry, to play an active role within the organization, they need to 
have sound technical and theoretical knowledge on sports. In addition, they need to have adequate training on topics such as economics, management, accounting, marketing and finance in order to properly manage the organization's financial status.

The efforts to make sports management an academic discipline have started at United States of America in 1957 with a sports management class in University of Florida (Lair, 2003). The first department of sports management has been founded in the year of 1966 at the University of Ohio (Stier, 2001; Laird, 2005). With the contributions of North American Society of Sport Management, which was established in 1986, there are currently more than 200 department that offer sports management and sports administration classes in their curriculums throughout North America (Humphreys \& Maxcy 2007). In 1996, the first master's degree programme was launched (Chalip 2006; Jones, Brooks \& Mak, 2008) thus sports management field has gained the ability to train its own educators.

In our country, schools of physical education \& sports and sports sciences faculties educate trainers, physical education teachers, sports experts, recreational experts and sports managers in order to realize sports services and sports organizations while maintaining the quality. This programme was first started with the establishment of "Gazi Elementary Master School and Behavioral Institute" in 1932, and continued to developed by the founding of Istanbul Anatolian Fortress Youth \& Sports Academy and Manisa Youth \& Sports Academy in 1975-76. The purpose of aforementioned academies is to educate trainers, youth leaders, administrators and experts, which were all regulated by the law no. 3530 Physical Education Act. Two academic departments, which were named Physical Education \& Sports Sciences and Physical Education \& Sports Management, continued education until 1982 but they were discontinued later on.

Sports Management departments have been re-offered within universities and as part of schools of physical education and sports from the year 1993 (Yetim \& Şenel, 2001). In addition, after joining the Bologna Process in 2001 and the realization of the Erasmus Thematic Network, namely Aligning a European Higher Educational Structure in Sport Science, across Europe, four main field about sports were defined as "Sports Management", "Physical Education Teaching", "Recreation" and "Trainer Education". Since then, sports education experts from 28 different countries and 70 common organizations have been trying to establish standards about creating a new teaching programs in sports education via various meetings and conferences (AEHESIS 2006, www.aehesis.com, 2018).

Jones, Brooks and Mak (2008) point out that the first sports management programs in USA were almost identical to Physical Education counterparts and curriculums intertwined greatly. The inability to achieve knowledge completeness, which is an outcome of the multi-discipline structure of sports management, and the need for standardization of curriculums, National Association for Sport and Physical Education (NASPE) and North American Society for Sport Management (NASSM) released a joint declaration in 1993 that tried to define basic knowledge base, which should be given to sports management students (www.nassm.com, 2018). The topics of the undergraduate courses, which were offered by NASPE/NASSM (2000), are listed as "Socio-economic dimensions of Sports", Leadership and Administration in Sports", Ethics in Sports Management", "Sports Marketing", "Sports Communication", "Budgeting and Finance in Sports", "Sports Economics", "Sports Law", "Management in Sports", "Field Application/Internship" (Parks, Quarterman \& Thibault, 2013).

After going through the aforementioned historical process, sports management departments continue to offer education in 58 universities that are in accordance with The Council of Higher Education. The purpose of these departments is to offer education to sports managers, who will work in The General Directorate of Sports, sports federations, sports clubs, municipalities, sports marketing field, sports press and public relations companies and all sports organizations. Every year 4000 sports managers graduate from these departments and try to find a job in different fields of the sector. Consequently, the experiences that are gained by the students of sports management departments become more pronounced throughout their education process. However, when the literature is reviewed, it is determined that the number of studies, in which sports management is thoroughly examined from different perspectives, is very low.

In this context, it imperative to obtain the views of academic personnel regarding sports management curriculum in order to determine their wants and needs and thus forming and updating the curriculums. The main purpose of this study is to assess the efficiency of the relevant process by examining the perspectives of academic personnel, who take part in sports management education, with a phenomenological approach. To this end, the following questions were tried to be answered in this study.

1. How do you evaluate Sports Management Curriculum?

2. How do you define the deficiencies in Sports Management Curriculum? 


\section{Method}

\subsection{Research Pattern}

The phenomenology pattern was used in this study, aim of which is to reveal views of academic personnel regarding sports management program. Phenomenology focuses on human experiences resulting from a social reality in order to understand that reality. In this context, experiences, which are related to a phenomenon, are queried (Ersoy, 2016). In this research pattern, the focus is on phenomena, which are determined as a reflection of individual's own perception and life style, and about which there is not enough data (Creswell, 2015). In this pattern, the meaning, structure and essence of one's experience about a phenomenon is examined. In other words, how people experience certain phenomena is tried to be defined in a methodological and thorough way (Patton, 2014). The phenomenon is observed and relayed as it has manifested and been experienced (Smith \& Eatough, 2006).

\subsection{Participants}

The data sources in phenomenology studies are people, who can relay their experience about the phenomenon that is the focus point of that study (Yıldırım \& Şimşek, 2011). The participants of this study is comprised of 10 academic personnel working in Yozgat Bozok University. Therefore, sufficient data were obtained via primary sources. While determining the participants of the study, criterion and maximum variation sampling methods, which are subsets of purposive sampling, were employed. Extra attention is paid to include members of different faculties in order to achieve maximum variation sampling. This way, maximum diversity of data was aimed using available means. Code names were used in order to protect anonymity of the participant while reporting the findings of the study.

Table 1. Demographic Properties of the Participants

\begin{tabular}{llll}
\hline Alias & Title & Education Level & Department \\
\hline Dr.1 & College President & Ph. D. & Trainer Education \\
Dr.2 & Sports Management Department Head & Ph. D. & Sports Management \\
Dr.3 & Deputy Manager & Ph. D. & Physical Education and Sports Teaching \\
Dr.4 & Deputy Manager & Ph. D. & Physical Education and Sports Teaching \\
Dr.5 & Instructor & Ph. D. & Trainer Education \\
Dr.6 & Instructor & Ph. D. & Physical Education and Sports Teaching \\
Dr.7 & Instructor & Ph. D. & Sports Management \\
Dr.8 & Instructor & Ph. D. & Sports Management \\
Dr.9 & Instructor & Ph. D. & Sports Management \\
Dr.10 & Research Assistant & Ph. D. & Sports Management \\
\hline
\end{tabular}

When Table. 1 is examined, it is observed that 10 eligible academic personnel ( 3 female and 7 male) participated in the study. While 5 of the participant teach at Sports Management Department, 2 teach at Trainer Education and 3 teach at Physical Education and Sports Teaching.

\subsection{Data Collection}

Semi-structured interview forms were employed for data collection purposes in the study. In semi-structured interviews, the researchers queries the participant with pre-determined questions that are prepared in accordance with researcher's goals. In addition, different question styles can be employed in order to conduct a more thorough interview and collect more in-depth data (Glesne, 2012).

The semi-structured interview form used in this study was developed by the researchers. While determining the questions for the interview form, three faculty members, who were experts in curriculums, assessment and evaluation, were asked to give opinion. In addition, it is noteworthy that these experts have all done research using phenomenology pattern. For as much, phenomenology, which is used for revealing true source of elements that comprise an experience by using participants' experiences, is dubbed to be an authentic member of qualitative research methods (Yılmaz \& Şahin, 2016). The interview questions, which were finalized by field experts, were subjected to examination by an academic in Turkish Language and Literature Department regarding syntax and grammar. Thus, a consistent set of questions were tried to be obtained. In the data collection forms and in accordance with the study's aim, two questions, "How do you evaluate Sports Management Curriculum?" and "How do you define the deficiencies in Sports Management Curriculum?" were directed at the participants.

The researchers conducted a pre-interview with the participants and relayed some information about the aim of the 
study. In addition, the participants were made aware that the researchers wanted to conduct the interviews at a suitable date and location for data collection purposes, and the interviews would be recorded if the participants gave consent. These pre-interviews were conducted in the offices of the researchers, who took place in data collection process. Afterwards, main interviews were conducted for data collection purposes. The main interviews were carried out at the pre-set date and place and lasted approximately 1 hour. Subsequently, all the recordings of the interviews were dictated and read by all researchers in order to grasp the whole structure of the data set.

\subsection{Data Analysis}

In this study, the collected data were analyzed using content analysis technique and employing NVivo 8 software package. The purpose of using content analysis is to find concepts and relations, which can help explain the collected data. Concepts lead to themes and this process makes easier to understand the phenomena. In other words, similar data is gathered around concepts and themes in order to enable and organization and interpretation, which leads to a more readable and understandable form for the reader (Yıldırım \& Şimşek, 2011). In the scope of content analysis, the data is coded and categorized (Merriam, 2015). Moreover, the analysis process comprises of stages such that categorization, classification of the categories and data, naming the categories. Within this context, the raw data was obtained and organized by digitizing the information gathered from interviews without any alteration. Subsequently, the data was fit into themes and defined with a descriptive narrative in accordance with the interview questions and the aim of the study. In order to maintain internal reliability of the study, direct quotes from the participants were used. The quotes are in italic style and participant's code name was used for the corresponding quote.

In order to achieve internal validity of the study, extensive consulting was employed and each participant was required to approve the documented audio recordings of their interviews. They were asked to indicate or complete the parts that they saw missing or insufficient. To maintain the external validity of the study, a detailed descriptive strategy was used; especially in the methodology part of the study, all followed steps were tried to be described in as much as detail as possible. At this stage, an outside expert, who did not take part in the study, was given information about the study and was asked to review the findings regarding consistency. As a result of this examination, it is concluded that the overlap between the raw data and the produced phenomenon components were present.

\section{Findings}

As a result of data analysis, the phenomenological components regarding sports management curriculum were found to be "General Evaluation of the Program", "Number, Duration and Content of the Courses", "General Knowledge Courses and Professional Knowledge Courses", "Program Outcomes", "Applications of Sports Management" and "Sectoral Status".

\subsection{General Evaluation of the Program}

While evaluating the curriculum, Dr. 1 relayed their view as "The program tends to observe the development of students in such a way that emphasizes learning process, determine student success during teaching-learning process, and assess and evaluate in order to pinpoint its own deficiencies." Dr. 9 indicated that it is important to be asked about their opinion during curriculum preparations since they are at the foundation of this program. Dr. 9 also expressed the program's better and worse parts, insufficient and defective fields with these words: "We should already be at the heart of this. Because we experience the good and bad parts of the program. I wish commissions were created to obtain expert opinions. It will more effective."

Dr. 2 expressed their thoughts on curriculum as "...students explore new topics with management science and introduction to sports science classes by using questioning as a tool. Through these classes, they get to know sports management department, make guesses about the department, create hypotheses, and work on the outcomes of these activities. Therefore, they take their first steps into sports management program by comparing the existing concepts with the new ones. I think this is program, which compounds the gains and makes topics easier to comprehend. The program is consistent with the goals of sports manager education in such ways that it encourages research, questioning, making use of information technologies, asking questions, student's incentive to access information and learn-by-doing approach."

In universities, there are general goals for students to gain certain skills such as possessing scientific values, knowing their topics of expertise, thinking about consequences of actions, acting harmoniously with society and environment. In the application stage of the goal, the presence of the student is a crucial concept. Dr. 8, who argued the importance of this concept, expressed their opinion as "Curriculum of Sports Management Programs assumes that the student has accumulated a certain amount of knowledge, built a foundation regarding education and will advance using this 
foundation. Even though it should be so, there are situations where reality will not match up with the assumptions. For students who did not build the necessary arsenal of information (judgment, problem solving skills, critical thinking, etc.), it is arguable that the instructor should start directly with the curriculum. Moreover, since there is such a problem and the strong possibility that every student in a classroom is not the same, a single policy within the classroom cannot be decided upon, which will even pronounce the existing problem more strongly."

While Dr. 4 argued "The program is oriented towards enabling skills for different fields of sports management", Dr. 6 commented in accordance as "we can say about the education medium at the department that applied classes and internships, which enhance the students' ability to learn by doing, are sufficient. Actually, in general, the program is more aligned with the students."

On the other hand. Dr. 5, who stated that the program is rather aimed at the mission and vision of the department than the students, said that "...executing the education activities by setting various goals and within a certain plan and program created the education program itself. Education programs guides the learning process in various areas such as defining short and long term objectives of each class, determining the content in alignment with the purposes of the education and extend this content over a certain period of time. I think that the education program, which we employ here in Bozok University, serves the concepts and themes that I mentioned earlier."

Dr. 3, who pointed out that there are some flaws about the equipment of the classrooms during the application of the program, emphasized these thoughts by stating "we do have technological means, however, from a sports management program perspective, I think that it is necessary to create a field-specific interactive video, film or a scenario, which I can get students to role-play aligned with the concept of each class."

Dr. 7, who pronounced the parts that constitutes handicap to the application of the program, stated these by these words: "the inadequacy of our physical means hinders the application of the program. The efficiency of applied classes affects the outcomes of the curriculum."

\subsection{Number, Duration and Content of the Courses}

Participant Dr. 5 explained that the classes in the department are adequate both in number and duration in these words: "The number of classes in 8 semesters is sufficient. When compared to other universities in Turkey, I think the number of classes is adequate right now." Regarding class durations, Dr. 10 said "In general, I can say that they are long enough. I find it adequate with respect to our curriculum and ECTS regulations of the department", and Dr. 3 stated that the class durations are sufficient from a gain point of view with the words: "Class durations are a little high and I think the reason for this is that lecture contents and gains are plentiful. It is not a disadvantageous situation when the students' development is considered." On the contrary, Dr. 9's views were such that "I think classes are a little too long. I also think that even though classes are lengthy, different activities, which will enhance the efficiency of both the teacher and the students, should be done more. We need change our classical approach to education by employing activity applications or projects."

Dr. 1 expressed that the classes tends to favor memorizing. Dr. 1 criticized the lecture contents to favor memorizing regarding outcomes with the words: "For example, in sports history class, individuals, who have contributed to Turkish sports, are being examined. The students, who are taking that class, memorize the lives of those given individuals. What is the gain here? Starting from there, the student should be guided towards the importance of contributing to the country or the ways of achieving that contribution. The students ask me whether they will be responsible for the life of Selim Sirr Tarcan. The students must be shown how to shape Turkish sports by learning about Turkish sports history. After that, they should take their place in the sports sector with their innovative ideas that will make a difference."

Dr. 8, who indicated that the number of classes are too high, conveyed their thoughts about the necessity of qualified instructors, who should be experts in their respective fields, while carrying out the curriculum. Dr. 8 expressed this message in these words: "...for example, we have only one instructor, who is an expert on sports management. Other instructors are from different fields." Dr. 7 indicated that curriculum mandates memorizing with this statement: “...some theoretical classes are leaning too much towards memorizing. There is not much left in students' memory just 1 year later. This should be solved."

Dr. 6, who criticized the time limit on applied and research classes, expressed their thoughts as "...the biggest problem about the program is that it is intense. We cannot make time for student as much as we like. Time limitation not only inhibits our ability to create activities, but also makes auditing more difficult due to high number of students in a given class."

Instructor Dr. 2 relays the importance of sports management education regarding its qualities with the following 
statement: "Qualification of an academic personnel is primarily related to whether he/she received their masters or Ph. D. from sports management departments." Dr. 2 stated that number of such instructors can rise in the future as "we do have a deficit when it comes to experts in our field. However, I believe it can be overcome in time."

Dr. 4, who finds the application quantitatively positive regarding elective courses, said that "...even though elective course pool is very big, the choices are limited. The student can prepare themselves for a management field of their choice with these elective courses."

\subsection{General Knowledge Courses and Professional Knowledge Courses}

General knowledge course are common courses, which are mandatory for all students in every university or college. They are mainly offered in the first years of curriculums and decrease in number towards graduation. On the contrary, professional knowledge courses are a group of courses, through which students learn their professional responsibilities, relationships, the process of organization and production. Dr. 1, who interpreted the courses regarding their content stated that "...general knowledge and professional knowledge courses constitute an important portion of the sports management program. Especially, 'Sports Economics', 'Sports Sociology', 'Sports Law', 'Sports Management', 'Communication', 'Sports Psychology' and 'Leadership in Sports Management' courses are the pillars of sports management field."

While Dr. 4 expressed their view on courses as “...one thing that I like is there are connection between topics. There are topics, which are relationally organized to follow one another. This enables successor topic to reinforce its predecessor", Dr. 3 stated that "for example, I do not think there is much merit in having so many exercise, training and health classes in sports management."

Dr. 2 relayed their thoughts with these words: "I think professional knowledge courses are highly efficient by goals being suitable and targets being clear and logical.”

Dr. 7 drew attention to general knowledge courses with the following statement: “...other than that, being highly skilled at using computers is a major factor. It is good that there are courses for the general education of students such as English, Reform History, and Computers."

Dr. 8, who voiced their thoughts on foreign language in alignment with other instructors' views and in favor of general knowledge courses, emphasized the importance of speaking a foreign language within professional life as "Let me say that if students want to work in sports organizations and do it at a higher level, it is a must that they speak a foreign language. We even prefer not one but two foreign languages.

\subsection{Program Outcomes}

Dr. 8, who said that the students should have necessary body of knowledge after graduation, stated their thoughts as following: "after graduation, it all comes down to whether you are qualified enough or not no matter the sector. In-house qualification, personal qualification, resource usage... since it is the only parameter that defines you in the sector. The more you are in touch and collaborating with outside organizations and qualified, the easier it is for you to fit in."

Dr. 10 expressed their views on the exams, which are made to extract program outcomes, with these words: “...it is problematic for making a qualitative assessment during evaluation that there are only mid-terms and finals for each student. Student evaluation should be more universal."

Dr. 4, who indicated that "the program offers a medium, which encourages creativity", also added that "the exam techniques used within courses are sufficient." Dr. 3, however, expressed that "...there are only mid-terms and final exams. In my opinion, it is crucial that the students are able to prepare, interpret and discuss a topic."

Dr. 9 declared that the exam and evaluation forms can change and different exam techniques should be employed with these words: "We can make students prepare a project. Students should be encouraged and supported in such a way that it breeds motivation to devise projects."

Dr. 2 said that "I think that the courses in the programs reflects department's mission and vision, the lecture halls are sufficient to carry out classes and students will attain necessary body of knowledge upon graduation.” In this context, Dr. 5 emphasized the necessity of sports management experts in the sector as following: "After graduating and entering the sector, it is a must that employed people have expertise in the field. They need to know sports, the structure and dynamics of it really well. They need to be trained both in theory and application." He also stated the need for inclusion of seminars and conferences in the program by saying "However, the program should be supported by case studies, which are conducted by speakers from the field, or seminars that focus on management." 
Dr. 5 relayed their thoughts as follows: "the students need to know the history of the organizations they will work for, the foundation of every department branch especially towards graduation but become an experts in just one branch. To this end, they need to take courses of important branches as both theoretical and applied classes. Our curriculum is suitable for this." Dr. 6 argued for an effective execution of the curriculum with these words: "in order to meet the goals of the program, lecture hall equipment, sports facilities, library services, offices of academic personnel, number of lecture halls, conference and seminar halls should be adequate."

Academic personnel indicated the importance of communication skills. Dr. 7 stated their thoughts as "the most important topic is communication skills. Communication skills of sports management graduates should be very high. I think it will be sufficient if they have strong communication and problem solving skills."

Dr. 2, who declared that the aim of the program is to increase efficiency by making use of information and skills, expressed their thoughts as "it is good that program gains and declarations about these gains are well understood by the students. Program offers legal and regulatory information about the profession. The students are intended to be trained with quick problem-solving skills." In addition, Dr. 2 described different services on different levels that are offered by the program with these words: when our curriculum is considered, the courses are mostly compliant to ERASMUS criteria. There are exchange programs in sports management."

Dr. 3, who argued that the students will graduate with the necessary arsenal of information, relayed their thoughts as "The program should be consistent with the academic personnel and the principles, aim and content of the education program. Education methods and techniques should effectively employ the materials in the education plan. Our existing sports management curriculum reflect this situation."

\subsection{Applications of Sports Management (Internships)}

Dr. 2, who is the head of department, conveyed the importance of applications of sports management course by saying "With the applications of sports management course, our students get a non-learn-by-rote education. The instructor is a guide. Students do not forget the topics covered in this course. They should get more experience in learn-by-doing strategy. Every course is important but, I think "Management Application in Sports" class should offer more contribution to the student than others. Since it is an applied course, it will contribute to the students' ability to solve problems that they will face in their professional lives."

There are examples of statements regarding this theme by the academic personnel, which are as follows: "The organizations, which students apply for internship, represent the sector" by Dr. 8; "...I think students will benefit from Amateur Sport Clubs Federation in Yozgat" by Dr. 9; "...we do not have the chance to carry out the curriculum exactly the same everywhere. Since federations are in big cities, there should be internship opportunities in Governor's Offices, Municipalities and Provincial Directorate of Youth and Sports" by Dr. 5. Dr. 10, who expressed that it would be more beneficial for students to prefer doing their internships in big sports clubs, explained what type of organizations are more suitable for internships as follows: "...the sports management internships must be carried out mostly in high level sports clubs, big organizations and sports companies. The internships must not become wastes of time."

There were some suggestions offered by instructors about the internships. Dr. 6, similar to those before them, pointed out that it is important to prefer more institutional organizations to carry out internships as follows: "A meeting should be held with The Board of Directors and students must be enabled in every possible way to get summer internships at every kind of private and public institutions". Moreover, Dr. 6 added that "for example, we sent students to local sports clubs but they do not have managerial structures. They do their management in the field and we should collaborate with more corporate entities". The only view of Dr. 7 about internships is its difference between theoretical courses and Dr. 7 stated this as "The need to go on field. I believe we are very good at relaying information in theoretical classes, however, internship is something else".

Dr. 1, who commented about the duration of internship not being sufficient, expressed that it would be more beneficial for student to work as an intern one day a week throughout the semester in these words: "One summer internship is not enough in my opinion. Instead, we have 5 courses during the semester and the $6^{\text {th }}$ one may be the internship". The instructors emphasized the importance of the applications of sports management. In this context, Dr. 4 said "At the end, one will learn more from internship. Instead of learning about something theoretically in the classroom, they will learn more effectively by application”. Dr. 3 stated that “...it is really important. Moreover, what is organizational behavior good for? What does it do in an organization, where there is a sports manager present? Aside from one summer internship, our students need to in the sector as observers and applicators. Our fields is very important..." 


\subsection{Sectoral Status}

The participants emphasized the importance of sectoral collaboration in sports management program and stressed out the fact that stakeholder organizations should take necessary step towards a solution. Regarding stakeholder organizations; Dr. 2, drew attention to a lack systematic cooperation in the sector with these words: "For the last two years, we are trying to get some feedback from stakeholders, namely provincial directorates, sports clubs, city representatives and private organizations and institutions. There should exist a systematic cooperation in this area. For example, the stakeholders can hold focus-group workshops".

Dr. 6, who stated that the sector needs qualified personnel in fields of application, expressed their thoughts as "there should be more application in the program, which is related to everyday life. More scientific and permanent qualitative education methods and techniques should be employed. The aim of the program is to improve students' critical, analytical and creative thinking skills. It is also to enhance their problem solving abilities. And this should guide the students towards research". In align with this context, Dr. 5 emphasized the need to include more people that understand the structure of sports by saying "It is a must that people working in this sector should be experts. They need to know the structure and dynamics of sports. It is crucial that they have both theoretical and practical training".

Dr. 4, who passed a general judgment about the program and underlined the importance of sectoral communication, disclosed their thoughts as "it is specifically important for graduates of the sports management program to develop and improve managerial communication skills. It will be beneficial if they practiced leadership applications". Dr. 1, on the other hand, articulated "There should be a collaboration while carrying out lectures with the applicators of sports management (sports management sector representatives, organizations and institutes, which students do their internships, Amateur Sports Clubs Federation, etc.)”.

Dr. 8 conveyed the lack of collaboration between the program and the sector due to insufficient opportunities with these words: "...there can be a lecture in the form of a conference with the representatives of the sports clubs. An administrator can give a presentation in the department, for example. However, because of the socio-cultural structure of Yozgat, students are unable to find sectoral outlets that are needed for sports management".

One of the skills that a sports manager should have is marketing in the sector and the program should provide this skill to the students. In this context, Dr. 7 said "If a sectoral task is assigned to one of our graduates, how helpful can they be? There should be applications that are geared towards administrative skills and students' knowledge should be enhanced".

\section{Discussion}

In this study, where the curriculums of sports management programs offered in sports sciences faculties and higher schools of physical education and sports were evaluated by academic personnel, six inter-related elements were laid out. These are, "General Evaluation of the Program", "Number, Duration and Content of the Courses", "General Knowledge Courses and Professional Knowledge Courses", "Program Outcomes", "Applications of Sports Management" and "Sectoral Status".

The findings of the study are in the direction of revealing general evaluation of the program as the first main element of the phenomenon of sports management curriculum, according to the participants. The participants also indicate that the program has been benefiting students in high level cognitive areas such as possessing scientific values, questioning, making use of technology, and learning-by-doing. The academic personnel pointed out that it is most fitting if the curriculum is prepared by themselves. They argued that the existing program is a sophisticated one, which includes courses like management science, sports management, sport economics, sports marketing, applications of sports management, experimental learning and internship, and it is also sufficient for the development of the students. Jones, Brooks and Marks (2008), who examined sports management programs in United States with respect to their curriculums, emphasized that the more diverse sports management gets as an academic discipline, the more flexibility in course content should be expected and it should be offered within different disciplines. In a study conducted by Orta et. al. (2010), it was determined that generally sports management, introduction to sports sciences, personnel management, human resources management and sports economics courses were offered throughout Turkish sports management programs.

Another finding of the study indicates that, according to the participants' points of view, another main element of the curriculum phenomenon is the number, duration and content of the courses. When participants' statements about the matter were reviewed, it is evident that the courses are sufficient in number and duration. The studies conducted on 
the needs of sports management programs are also in favor of this study's findings (Gouws, 1993; Chen, 2004; Desensi et. al. 1990; Hardy, 1987; Hatfield et. al. 1987; Davis, 1987; Jamieson 1980; Afthinos 1993; Parkhouse 1987; Skipper 1990; Jennings 1984). The duration of the classes were generally declared as adequate, however, the content of the courses were criticized to be based on memorization. It was also criticized that instructors would have to offer courses that are different than their field of expertise due to both quality and quantity of academic personnel. It seems to be common ground that an academic personnel should have acquired their master's or doctoral degree in sports management department in order to offer courses in the curriculum. Another emerging problem is that even though the elective course pool is pretty big, students have limited choices. The common verdict given by instructors about the contents of the courses is that they are completely geared towards preparing students to the sector after graduation. Parkhouse (1987) mentioned in a study the importance of having necessary body of knowledge among graduates and consulted the opinions of employers. In the study, it was revealed that the curriculum was prepared using academic experiences and the employers were not happy about the lack of application. The study concluded that sports management curriculum should meet the needs of respective professional spectrum.

Yet another finding of the study, which is in alignment with the participants' perspectives, is that there are certain gains in production stage via professional knowledge courses. The instructors emphasized the importance of knowing a foreign language when it comes to landing a job in sports clubs. They even said one foreign language may not be enough and the second one will give students an edge. In a study conducted by Sunay (2012) and named "Views of Sophomores Regarding Sports Management Curriculum", it was concluded that English courses needed to become effective and more attention should be paid to translations from relevant sources. In a study done by Nikolaidis (1995), where standards for sports management curriculum were tried to be determined, it was emphasized that courses from NASPE/NASSM curriculum standards, validity of which had already been proven, should be included in the programs. The researcher also pointed out that it is important to have similar sports management curriculums thorough out Europe in order to train internationally qualified sports managers.

One other element, according to the participants, was program outcomes. It was common amongst instructors that students need to have necessary arsenal of information upon graduation. The qualification was dubbed to be a must no matter what the sector is and the significance of personal competence and communication was also pronounced. Lambrecht (1987) determined the necessary qualifications for both big and small sports club management and discovered that the qualification requirements for small club management is rather different. During the assessment of the program outcomes, just mid-terms and final exams were found to insufficient, and the common opinion was that there needed to be an application of a free project. It can be said that the participants agreed upon the fact that evaluation should be carried out by considering performance within the education process. It was considered to be a good practice to support the program with a scientific project, which would supply a creativity-enabling medium. The lack of conferences and seminars can be considered as a shortcoming of the program.

Another element that is revealed in the study is the applications of sports management. It is considered to be the most valuable course by the academic personnel. It was a common message that internships in the program should be done in higher level clubs, organizations and sports companies. It was agreed upon that even though theoretical courses in the programs laid out a good foundation, the students needed to acquire different experiences in the sector. It was evident that the sophomores of sports management program preferred to take management application (internship), public relations, communication and mainly management-related courses. In a Williams and Colles (2009) study about evaluation of program outcomes with internship, the researchers emphasized the place and significance of internship within the program. In another study by Çoknaz and Bulut (2013), the courses used in field application mainly gathered around human communication, communications between organizations and sports management. They indicated that a sports would be more effective by using social skills that were acquired during internship. In a study, where Çoknaz (2014) examined the place of internship in sports management, it was pointed out that internship will benefit the student within the activities of learning. From this point of view, it can be said that the learnt information becomes more permanent with the applied courses in sports management.

The last finding of the research is the sectoral status element. While evaluating the sports management program, the instructors pointed out that courses, which will fulfill the needs of the sector should be included in the curriculum and there is a need for people with necessary qualifications in the applications of sports management. Nikolaidis (1995) underlined the importance of a sector-oriented curriculum in overcoming the employment problem in their study on sports management, which also supports this study's findings. The instructors argued that there should be more applied courses in the program and pointed out to the collaboration with stakeholder institutions in order to enhance the students' critical, analytical and creative thinking skills. Lizandra (1993) examined the accreditation procedure and the validity of curriculum standards of NASPE/NASSM with academicians and stakeholder 
representatives, then determined that both procedure and the standards were widely accepted.

\section{Suggestions}

In this study, where qualitative research and descriptive phenomenological pattern was used, the meaning of sports management curriculum phenomenon and the core elements that constitutes this phenomenon were examined in accordance with the perspectives of the academic personnel. Research findings showed that curriculum phenomenon comprised of six elements (general evaluation of the program; number, duration and content of the courses; general knowledge and professional knowledge courses; program outcomes; sports management applications; sectoral status). It is thought that there is a shortage of research even though there are some studies in the literature. In this context, it can be proposed that the structural elements of sports management curriculum phenomenon, which is the focus of this study, can be used as a frame of reference for future studies. Considering a rather significant finding of the study, namely "curriculums can be prepared with qualified managers and employees in the sector", some measure can be taken regarding sectoral collaboration. Furthermore, based on the findings, individuals, who are charged with running sports management departments, should come together not only for a coordinated effort for curriculum preparations but also for an image planning study, which will serve as a means to better understand the profession. In conclusion, regarding sports management application, it is proposed to increase the quantity of opportunities by supplying the necessary legalizations. It is possible to conduct future studies in this topic using different research methods.

\section{References}

AEHESIS Tematik Ağ Projesi, (2006). Spor Bilimleri Eğitimini Avrupa Yükseköğretiminde Uyumlaştırma. 3. Yıl proje raporu. Retrieved from http://www.aehesis.com

Afthinos, Y. D. (1993). An analysis of perceived competencies of sport for all managers in Greece. Unpublished doctoral dissertation. New York University, New York.

Cankalp M. (2005). Sporda yönetim ve organizasyon 2, Nobel Yayınları, Ankara.

Chalip, L. (2006). Toward a distinctive sport management dicipline. Journal of Sports Management, 20, 1- 21. https://doi.org/10.4236/oalib.1102681

Chappelet J. L. (2009). A glocal vision for sport (and sport management). European Sport Management Quarterly, 9(4), 483-485. https://doi.org/10.1080/16184740903331960

Chen, C. Y. (2004). An examination of the competencies needed by sport managers in Taiwan. Yayınlanmamıs doktora tezi. ABD: College of Graduate Studies University of Idaho.

Çoknaz D. (2014). Internship in sport management: A case study in Turkey. International Journal of Academic Research, 6(1), 7-56. https://doi.org/10.7813/2075-4124.2014/6-1/B.7

Çoknaz, D., \& Bulut D. (2013). Spor yönetiminde alan uygulaması: algılar, beklentiler ve sorunlar. Uluslararası Hakemli Akademik Spor Sağllk ve Tip Bilimleri Dergisi, 8(3), 55-67.

Creswell, J. W. (2015). Nitel araştırma yöntemleri (2. Baskı) (Çev. Edt. M. Bütün ve S. B. Demir). Ankara: Siyasal Kitabevi.

Davis, K. A. (1987). Selecting qualified managers: recreation/sport management in private sector. Journal of Physical Education, Recreation, and Dance, 58(50), 81-85. https://doi.org/10.1080/07303084.1987.10603904

Desensi, J. T., Kelley, D. R., Blaton, M. D., \& Beitel P. A. (1990). Sport management curricular evaluation and needs assessment: a multifaceted approach. Journal of Sport Management, 4, 31-58. https://doi.org/10.1123/jsm.4.1.31

Doğu, G. (2011). Spor yönetimi ve organizasyon. Spor bilimlerine giriş. In Nevzat Mirzeoğlu (Ed.). Ankara: Spor Yayinevi.

Ersoy, A. F. (2016). Fenomenoloji. Eğitimde nitel araştırma desenleri. (Edt: A. Saban ve A. Ersoy). Ankara: Anı Yayıncilik.

Glesne, C. (2012). Nitel araştırmaya giriş. A. Ersoy ve P. Yalçınoğlu (Çev. Ed.). Ankara: Anı

Gouws, J. (1993). Sport management curricula in Rand Afrikaans University, South Africa. Journal of Sport Management, 7, 243-248. https://doi.org/10.1123/jsm.7.3.243 
Hardy, S. (1987). Graduate curriculums in sport management: the need for a business orientation. Quest, 39, $207-216$. https://doi.org/10.1080/00336297.1987.10483874

Hatfield, B. D., Wrenn, J.P., \& Bretting, M. M. (1987). Comparison of job responsibilitie of intercollegiate athletic directors and professional sport general managers. Journal of Sport Management, 1, 129-145. https://doi.org/10.1123/jsm.1.2.129

http://www.nassm.com/InfoAbout/SportMgmtPrograms Erişim tarihi: 14-06-2018.

Humphreys, B. R., \& Maxcy, J. (2007). The role of sport economics in the sport management curriculum. Sport Management Review, 10. https://doi.org/10.1016/S1441-3523(07)70010-4

Jamieson, L. M. (1980). A competency analysis of recreational sport personnel in selected institutional settings. Unpublished doctoral dissertation, USA: Indiana University.

Jennings, M. W. (1984). Entry level competencies for recreational sports personnel in selected institutional settings. Unpublished doctoral dissertation, USA: North Texas State University.

Jones, D. F., Brooks, D. D., \& Mak, J. Y. (2008). Examining sport management programs in the United States. Sport Management Review, 11(1), 77-91. http://dx.doi.org/10.1016/S1441-3523(08)70104-9

Lair, C. (2003). Perceptions of sport management curriculum and the Naspe Nassm approval process: an analysis of undergraduate sport management academcians. Doktora Tezi. USA: Ohio University.

Laird, C. (2005), The influence of sport management program characteristics on academician perceptions of NASPE-NASSM approval. The Smart Journal, 1(2), 4-13.

Lambrecht, K. W. (1987). An analysis of the competencies of sports and athletic club managers. Journal of Sport Management, 1, 116-128. https://doi.org/10.1123/jsm.1.2.116

Lizandra, M. (1993). Sport management curricula: identification of minimum core content areas and courses to be included in each content area for undergraduate and graduate (master's) sport management programs. Doktora Tezi. USA: Temple University.

Merriam, S. B. (2015). Nitel araştırma: Desen ve uygulama için bir rehber. (3. Baskı). (Çev. Edt. S. Turan). Ankara: Nobel Yayıncilik.

Nikolaidis, D. (1995). Identification of core courses necessary for the development of sport management curricula in the European Community: Academicians vs Practitioners, UMI, Ann Arbor, MI, USA.

Orta, L., Albayrak Kuruoğlu Y. \& Beşiktaş M.Y. (2010). Türkiye’ de spor yönetimi eğitim-öğretim programlarının, bu alandaki uluslararası programlarla karşılaştırılması. 11. Uluslararası Spor Bilimleri Kongresi, Antalya.

Parkhouse, B. L. (1987). Sport management curricula: current status and design implications for future development. Journal of Sport Management, 1, 93- 115. https://doi.org/10.1123/jsm.1.2.93

Parks, J. B., Quarterman, J., \& Thibault, L. (2013). Çă̆daş spor yönetimi. Çev. Ed. Doğu, G., Sevimli, D., Durusoy, E.A., spor yönetimine giriş. Ankara: Akademisyen Yayınevi.

Patton, M. Q. (2014). Nitel araştırma ve değerlendirme yöntemleri. (M. Bütün ve S. B. Demir, Çev. Edt.). Ankara: Pegem Akademi.

Skipper, W. T. (1990). Competencies for collegiate sports facility managers: implication for facility management curricula model. Unpublished Doctoral Dissertation. USA: University of Arkansas.

Smith, J. A. \& Eatough, V. (2006). Interpretative phenomenological analysis. In G. Breakwell, C. Fife-Schaw, S. Hammond, \& J.A. Smith (Eds.), Research Methods in Psychology, (3rd ed.). London: Sage.

Stier, W. (2001). The current status of sport management and athletic (sport) administration programs in the $21 \mathrm{st}$ century at the undergraduate and graduate levels. International Journal of Sport Management, 2(1).

Sunay H. (2012). Spor yöneticiliği bölüm müfredat programına ilişkin son sınıf öğrencilerinin görüşleri. 12 Uluslararası Spor Bilimleri Kongresi., Denizli.

Williams, J., \& Colles, C. (2009). Assessment of student learning outcomes: the role of the internship portfolio in management assessment. Sport Management Education Journal, 3(1), 47-65. https://doi.org/10.1123/smej.3.1.47

Yetim, A.A., \& Şenel, Ö. (2001). Türkiye'de spor yöneticisi yetiştirme faaliyetlerinin görünümü. Milli Eğitim Dergisi, 150. 
Yıldırım, A., \& Şimşek, H. (2011). Sosyal bilimlerde nitel araştırma yöntemleri (8. Baskı). Ankara: Seçkin.

Yılmaz, K., \& Şahin, T. (2016). Eğitim fakültelerindeki araştırma görevlilerinin meslekideneyimlerinin incelenmesi: Araştırma görevlisi olmanınanlamına ilişkin fenomenolojik bir çalışma. Marmara Üniversitesi Atatürk Ĕgitim Fakültesi Ĕ̈itim Bilimleri Dergisi, 44, 143-168. http://hdl.handle.net/11424/6037 